\title{
電子計算機による赤外線吸収スペクトルデータの 検索法に関する一考察*
}

\author{
近，藤 赫 文**，中 川裕 彦***
}

\author{
A Consideration on Computer Search System for Retrieval of Infrared Spectrometric Data* \\ by Akifumi Kondo**, Hirohiko Nakagawa***
}

\begin{abstract}
Summary : This report describes the computer search system for retrieval of infrared spectrometric data. The features of this system are as follows.

1. The elements used in this system are the wave length and the intensity of absorption bands. The data of the unknown substances are compared with those of the known substances in the master tape.

2. The check is done by the variance of the shift of wave length, the number of corresponding absorption bands and the correlation coefficient of the intensities between the known and the unknown substances. When the corresponding absorption bands are not agreed with the master data, penalties are imposed on the variance.

The known substances in this experiments consist of two blocks; one is composed of 27 well-known polymers, and the other is composed of 55 organic substances which have infrared spectra similar to the samples. Obstructions due to errors in the measurement and impurities contained in the samples can be eliminated to a large extent by this system.
\end{abstract}

\section{1 緒 吾}

赤外線吸収スペクトルは物倎の同定手段として有機化学分野 で広く利用され，また同定の自坋化む種々試みられているいーい。 本報では郝外線吸収スペクトルの梌索の自動化に関しモデル的 実酸による検討を行い，良好な結果が得られたので報告する。 赤外線吸収スペクトルはかなり簡単な分子でも非常に複雅な スペクトルを与える場合が多く，この複雑さを利用して未知物 贸の吸収スペクトルと既知物倎の吸収スペクトルとの照合によ り梌索同定することは以前より広く行われていだ，の。 赤外線吸收スペクトルの吸收帯は先端の波長, 強度, 広さ， 形照等の要素で構成され，そのちちの数量化の简単なものは波 長と強度であるが，分光器や試料の形状等が違っても信頼性が あるのは波長で, 強度については相対的な大小が大体において 信頼できる程度であるとされている。本研究の特徽は吸収帯の 先端の波長と蚛度を検索の要素とし, 検索過程において波長の すれの分散，対応する吸収帯の数及ひ吸収強度の相関係数を用 いていることである。また，不䋊物の混入による検索の妨害の 除去と测定誤差の処理の勃果についても検討した。

2 システム

\section{1 システムの概要}

既知物倎の赫外線吸収スペクトルの主要な吸収帯についてそ の先端の波長と透過率をあらかじめ磁気テープ(マスターデー 夕）に入れて招き，未知試料の赤外線吥収スペクトルについて

\footnotetext{
* 昭和 49 年 10 月 4 日受理

** 株式会社テーケーエス环境技術センター東京孛業所（252 神奈川県 高座郡綾濑町早川 2743-1) Tokyo Laboratory, T.K.S. Environment Technical Center Co., Ltd. (2743-1, Hayakawa Ayase-cho, Koza-gun, Kanagawa-ken 252)

*** 株式会社鐵興社 Tekkosya Co., Ltd.
}

は同様なデータを紙テープ (トランズデータ) で入力し, マス ターテープのデータを検索する。処理スピードを上げるためマ スターデータはポリマーとポリマー以外の有機化合物の二つの ブロックに分け，プロック内より最大 100 件ずつ読んで計算機 内で処理するようにした。計算機処理の結果は既知物啠データ が最大 10 件まで選び出され，アウトプットされる。 なお後述する波長のずれの許容限界 $(\varepsilon)$ 及びペナルティーコ ンスタント( 応がずれた時に分散に脚行る定数）をあらかじか指定すること により,アウトプットの件数は变化する。本システムのフロー を Fig. 1 に示す。

\section{2 既知物質の赤外線吸収スペクトルデータ}

二つのブロックに区分してマスターテープに入れた既知物梊 データはブロック1ではポリマーを対象とし代表的なポリマー 27 件を Sadtler Standard Spectra Monomer \& Polymer り選じ出しマスターデータとした。またブロック2ではポリマ 一以外の有機化合物を対象とし，被梌試料に対応する既知物斦 及びこれにスペクトル上類似した物诈を含め計 55 件を Sadtler Standard Spectra より選び出しマスターデータとした。類似 スペクトルの選び出しには “赫外スペクトル検察装置”’を用 い5万件より選び出した。

\section{3 赤外分光光度尌}

使用した赤外分光光度計は日立製 EPI-G 3 で，検索に使用 した波長箸囲は $2 \sim 15 \mu$ である。

\section{4 兴子計算柲}

使用した電子計算機は富士通（株）の FACOM 230-25 で 次のよらな樓成からなっている。

CPU (本体) F 230-25 (32 KB)

DR (ドラム) $1024 \mathrm{~KB}$

$\mathrm{MT}$ (磁気テープ) 6 台 (5ち1台使用) 


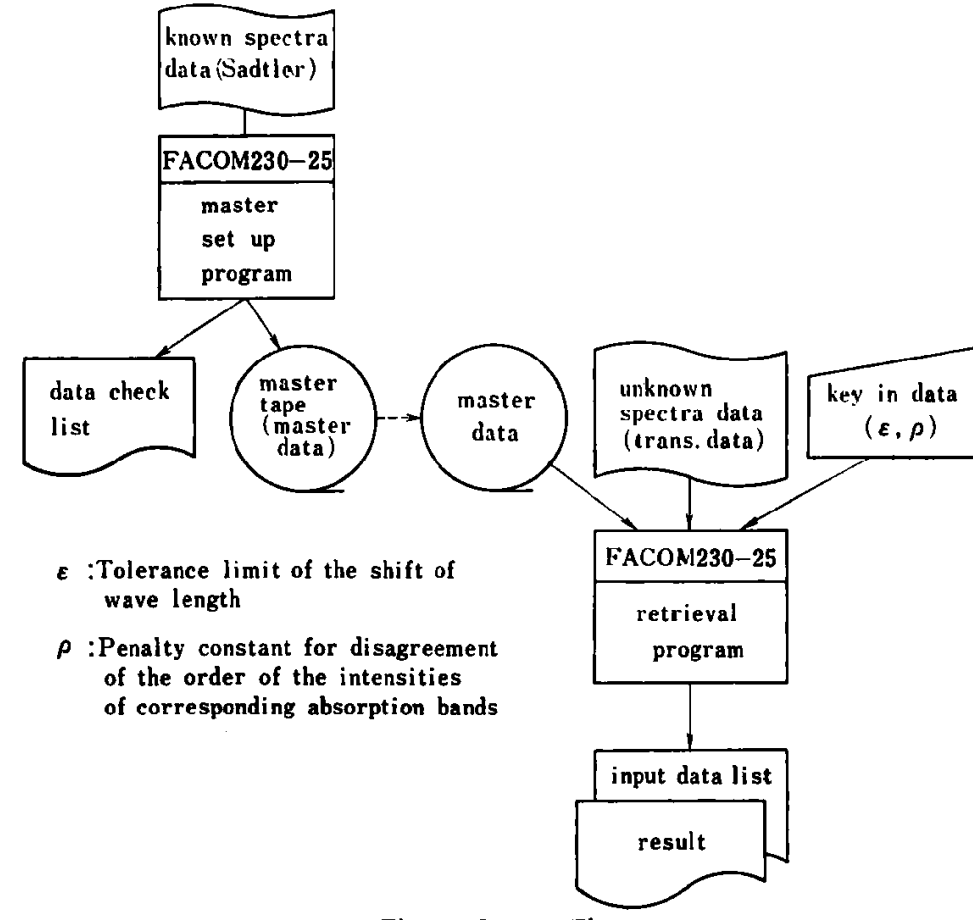

Fig. 1 System Flow

PTR（紙テープリーダー）1台

LP (ラインプリンター) 1 台

なお本システムのプログラムは FORTRANを用いた。

3 ソフトウェア

\section{1 ソフトゥェアの梅要}

検索には被検試料の吸収帯が通常不純物を含むために対応す る既知物梊の吸収帯の数よりも多いことを利用して，マスター テーブにファイルされた既知物質データを被検訊料データに照 台させる方法を採用した。

もしマスターデータ中に対応する既知物兵があるならこの 吸収スペクトルを被険試料の吸収スペクトルに照合させると不 純物による検索の妨害や測定誤差等がなければ，吸収スペクト ルは全て対応するはずである。実際には不純物が存在する場合 が多く，また测定誤差等があるので全く一致することはほとん どない。本報ではあらかじめマスターデータには既知物質の吸 収スペクトルより主な吸収帯を最大 10 個選び，また被検試料の 吸収スペクトルより主な吸収帯を最大 15 個選び照合し,対応す る吸収带を探索する方法を用いた。検索手段としては波長のば らつきを示す分散，対応する吸収带の数及び吸収强度の相関倸 数を用いた。検索結果は吸収帯の数による判定を通過したデー タのうち,相関俰数の大きな最大 10 件の既知物所データがアウ トプットされる。プログラムの簡単なフローを Fig. 2 に示す。

\section{2 既知物質データ}

既知物梊データは物啠名，ブロックコード，コード番号及び 吸收帯の先端の透過率の低いものから順に最大 10 個選び, 波

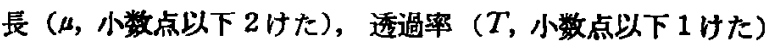
を記䟿しマスターデータとする。なお既知物澌データ 1 件 (1 レコード) の長さは 100 バイトで磁気テープには1フィート 24 件記憶できる。

吸収带の選択基準は次のごとくである。
1. 吸収带が重なっている時は吸収带の先端の波長 間隔が $0.1 \mu$ 以下で透過乎の差が 20\% 以下の埸合は 同一吸収帯とみなす。

2. 透過事が等しい時は短波長の方を優先する。

\section{3 試料テータ}

試料データは検索筑囲を指定するブロックコード及 び 3.2 と同栐に吸収带を最大 15 個選び波数 $(P$, 少数 点以下なし)，透過率 $\left(T^{\prime}\right.$ ，少数点以下 1 けた）を記 録しトランズデータとする。

\section{4 分散の計算}

試料デー夕は波数 $(P)$ と透過率 $\left(T^{\prime}\right)$ で入力され るのでこの波数をプログラム中で波長 $\left(\mu^{\prime}\right)$ に换算す

る。Fig. 2 に示すごとくまず分散が計算される。 今マスターデータにある一つの既知物所の吸収帯デ 一タの数を $n$, 試料の吸収带データの数を $n^{\prime}$ とナる。 データは各々透過率の低い順に入力されている。既知 物兵データの波長 $\left(\mu_{i} ; i=1 \sim n\right)$ と試料データの波 長 $\left(\mu_{j}{ }^{\prime} ; j=1 \sim n^{\prime}\right)$ を照合する。

照合はまず $i=1, j=1$ すなわち既知物啠の波長 $\mu_{1}$ と試料の波長 $\mu_{1}{ }^{\prime}$ で行う。今波長のずれの䈞容限界を ととする。条件

$\left|\mu_{1}-\mu_{1}^{\prime}\right| \leqq \varepsilon$

が満たされたら $e_{1}^{2}$ は

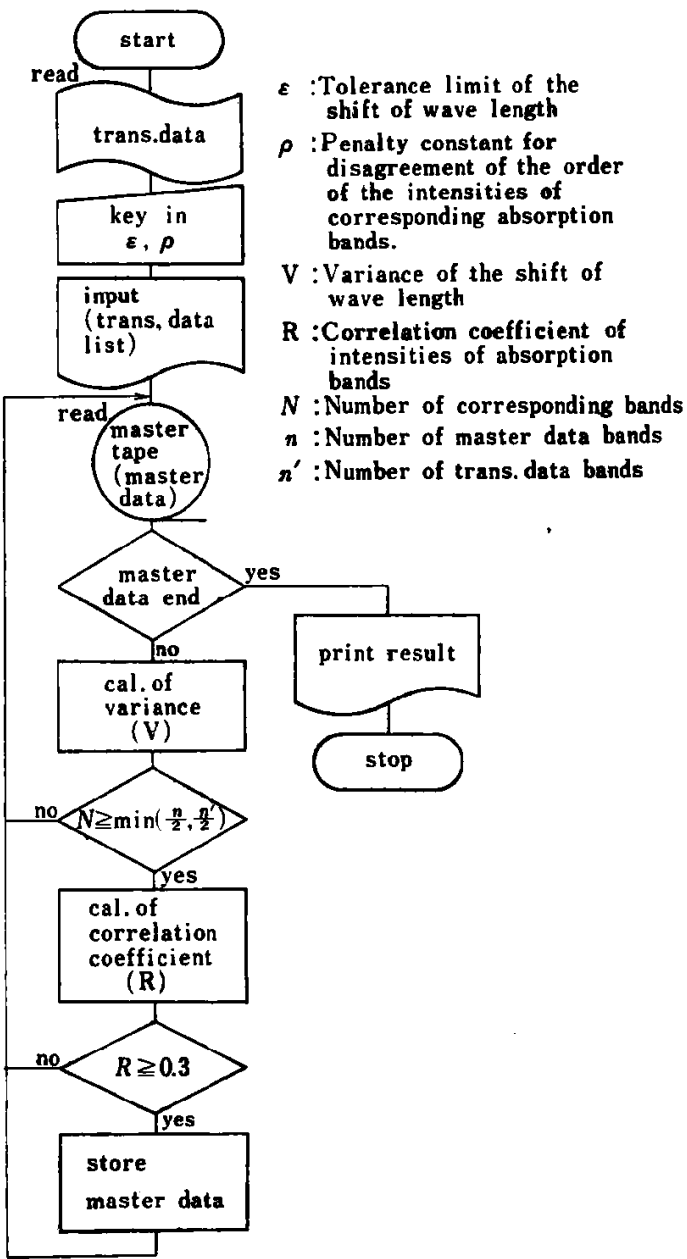

Fig. 2 Program Flow 


$$
\boldsymbol{c}_{1}^{2}=\left(\mu_{1}-\mu_{1}{ }^{\prime}\right)^{2}
$$

とする。もし条件 (1) が洣足されなければ $j$ を $2,3, \cdots$ と， $\boldsymbol{n}^{\prime}$ まで変化させ满足される組を探す。 $j=j_{0}$ の時

$$
\left|\mu_{1}-\mu_{j a^{\prime}}\right| \leqq \varepsilon
$$

となったならば

$$
e_{1}^{2}=\left\{\left(\mu_{1}-\mu_{j 0}{ }^{\prime}\right) \rho^{b}\right\}^{2}
$$

とする。この時の $\rho(>1)$ は先に述べたペナルティーコンスタ ントで, bは対応しなかった個数でこの場合 $j_{0}-1$ である。こ のことはたとえ波長の差は $も$ 以内であっても透過事が順序に反 しているので ค というペナルティーを与えている。

次に $j=2$ の時, $i=1, j=1$ で刘応がついた特は $j$ は 2 か

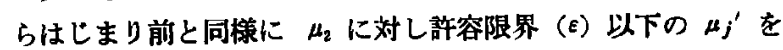
梊す。しかし $j=2$ の特, $i=1, j=2$ で対応がついたとする と, 今度は $j$ は 2 以外の番号, 才なわち $1,3,4, \cdots$ に対して 対応を調べる。ここで $i=2$ の時 $j=4$ で対応がついた，すな わち $\left|\mu_{2}-\mu_{4}^{\prime}\right| \leqq \epsilon$ となったとする。この時 $j=1$ と 3 の2個 所については沜底がつかなかった。この值を $b(=2)$ とおく。 この時

$$
e_{2}^{2}=\left\{\left(\mu_{2}-\mu_{4}^{\prime}\right) \rho^{2}\right\}^{2}
$$

と計算する。すなわち $i$ が $1,2,3, \cdots, n$ までに対し $j$ \& 1 , $2,3, \cdots, n^{\prime}$ まで野かすが, 対応のついた $j$ は逐次除いて行き, その間に対応がつかなかった個数を数えbの值とナる。

同様にして $i$ を $3,4, \cdots と n$ まで変化させ, 采件式 (6)

$$
\left|\mu_{i}-\mu_{j}\right| \leqq \varepsilon
$$

を满足したら

$$
\begin{aligned}
& e_{i}{ }^{2}=\left\{\left(\mu_{i}-\mu_{j}{ }^{\prime}\right) \rho^{b}\right\}^{2} \\
& \text { ただしbは対応のつかなかった個数, } \rho>1
\end{aligned}
$$

を計算する。式(6)の条件を满たす $j$ がなかった侍注 $e_{i}^{2}=0$ とし,この個数を数える。この倜数か $m$ 個あったとする。こ の時の条件式 (6) を满足した組を $N$ 個とすると

$$
N=n-m
$$

である。 $N$ は式 (9)

$$
\operatorname{Min}\left(\frac{n}{2}, \frac{n^{\prime}}{2}\right) \leqq N
$$

を满足するものについて分教 $(V)$ は

$$
V=\left(\frac{1}{N} \sum_{i} e_{i}^{2}\right) \times 2^{m}
$$

で計算する。 $2^{m}$ は対応する吸収带が存在しない時さらに大き なペナルティーを課すことを示す。

\section{5 対応する嗳収帯の数による判定}

分散で算出された対応する㖟収带の数 $N$ が既知物啠の吸収 率データの数 $n$, 又は試料の吸收带データの数 $n^{\prime}$ のいずれか の小さい方の少なくとも半分以上の場合は 3.6 相関俰数の計算 へ進み，半分以下の場合は次の既知物犋データによる照合に移 る。

\section{6 相関係数の計算}

3.5 対応する吸収帯の数による判定で通過した 既知物啠 デ 一タ及び武料データについて透過率 $T, T^{\prime}$ の逆数の対数をそ れぞれ $A, A^{\prime}$ とし，3.4 の時の条件 (6) を満足したデータの 組について式 (11) に従い相関係数を算出し，

$$
R^{\prime}=\frac{\sum_{k}\left(A_{k}-\bar{A}\right)\left(A_{k}^{\prime}-\bar{A}^{\prime}\right)}{\sqrt{\sum_{k}\left(A_{k}-\bar{A}\right)^{2}} \cdot \sqrt{\sum_{k}\left(A_{k}^{\prime}-\overline{A^{\prime}}\right)^{2}}}
$$

ただし

$$
\bar{A}=\frac{1}{N} \sum A_{k}, \quad \bar{A}^{\prime}=\frac{1}{N} \sum A_{k}^{\prime}
$$

式（12）により自由度調整した值を算出する。

$$
R=\frac{N}{N-1} R^{\prime}
$$

この值を吸収強度の相関係数として使用する。

実際のスペクトルにおいては一般に本斦的な 100\% ラインが 記録紙の 100\% ラインと一致することはないので $A_{k}, A_{k}{ }^{\prime}$ は 吸収帯の正しい吸光度ではない。しかしこの違いが $R$ の值に 与える影俥はあまり大きなものではないから便宜上，上に定義 した $A, A^{\prime}$ を用いてもさしつかえない。なお $R<0.3$ の場 合は次の既知物倎データによる照合に移る。

計算機で検索が終了すると結果はラインプリンターに打ち出 される。プリントアウトされる内容は既知物斦名, ブロックコ 一ド,コード番号, 吸收帯の数 $(n)$, 対応寸る吸収帯の数 $(N)$, 自由度 $(N-1)$, 分散值, 相関係数と各波長, 波数, 透過率及 び*印である。*印はプリントアウトされた中で波長のずれの 分散が最も小さいか, 対応寸る吸収帯の数が最も大きいか, 又 は吸収強度の相関係数が最も大きいるのにつきそれぞれ 1 個つ けられ結果を見やすくしている。従ってアウトプット中波長の ずれの分散が最小, 対応する吸収帯の数が最多で㖟収強度の相 関釈数が最大のものには*印が3 個つけられる (Fig. 3 参 照)。

\section{4 実験}

2 及び 3 で述べた桧索法を用いて次のごときモデル的実験を 試み、ほぼ満足すべき結果を得た。

\section{1 陚料}

実䙲に供した試料を Table 1 に示す。サンプル No. 1, 2 はアセトンに溶解した試料を $\mathrm{NaCl}$ 板上で烝発させフィルム を作りサンプル No. 3, 4 は $\mathrm{NaCl}$ 板によるサンドイッチ法 にて，そしてサンプル No. 5, 6,7 は $\mathrm{KBr}$ による锭郕法にて 赤外線吸収スペクトルを測定した。

\section{2 既知物空の赤外線吸収スベクトル}

マスターテープのブロック I”に対応する既知物梊と代表的ポリマーを合計 27 件 Sadtler Standard Spectra Monomer \& Polymer より選び，ブロッ ク 2 ではジ-2-エチルヘキシルフタレート (DOP) およびフタ ル酸とスペクトル上それらに類似した既知物梊台計 55 件を Sadtler Standard Spectra より選びそれぞれマスターデータ

Table 1 Samples in Trans. Data

\begin{tabular}{c|c|l|c}
\hline $\begin{array}{c}\text { Sample } \\
\text { No. }\end{array}$ & $\begin{array}{c}\text { Sample } \\
\text { Name }\end{array}$ & \multicolumn{1}{|c|}{ Composition } & $\begin{array}{c}\text { Number of } \\
\text { Bands }\end{array}$ \\
\hline 1 & Sample H & polyvinyl acetate & 11 \\
2 & Sample I & Vc-VAc-MA terpolymer & 11 \\
3 & DOP PURE & DOP (86:13:1) & 10 \\
4 & D 10*T 1 & DOP-TCP (10:1) & 10 \\
5 & F PURE & phthalic acid & 11 \\
6 & F 20*M 1 & phthalic acid-MA(20:1) & 12 \\
7 & F 10*M 1 & phthalic acid-MA(10:1) & 12 \\
\hline \\
Vc: vinyl chloride & DOP : di-(2-ethylhexyl) phthalate \\
VAc: vinyl acetate & TCP : tricresyl phosphate \\
MA : maleic acid &
\end{tabular}


にフォイルした。

\section{3 結果およひ考察}

波苌のずれの許容限界 ( $(\varepsilon)$ の値を $0.1,0.2$, ペナルティーコ ンスタント $(\rho)$ の值を $1.0,1.3,1.6$ と順次変化させた場合の アウトプット中対応する既知物诈の波長のずれの分散，吸収強 度の相関保数，対応する吸収带の数及びアウトプットの数を Table 2 に示す。単一成分である “Sample H”, “DOP PURE” 及び “F PURE” に対応する既知物啠データのほと んどがそれぞれ波長のずれの分散が最小，対応する吸収帯の数 が最多で吸収強度の相関係数が最大であるため*印が 3 個つい た。 “Sample I" については吸収スペクトル上非常に類似した 物犋 (Sadtler No 1650) があったため, 波長のずれの分散等 の值から一意的には対応する既知物倎を決められなかった。

“DOP PURE” 及び “F PURE” と比較しサンプル No. 4, 6, 7 の DOP 系及びフタル酸系の混合物においてはアウト プットされた既知物畝データの数は多くなる傾向であったが, 対态する吸收帯の数が 7 個以下の既知物所がほとんどである。 それら主成分に対応しない既知物質の波長の才゙れの分散の值は
ペナルティーを設けることによりさらにはっきりと主成分に対 応しないことを示した。

本モデル的実験はマスターデータが少ないため大量のマスタ ーデータの場合について結諭ゔけることはできない。しかし 約 5 万件の中より被検試料とスペクトル上類似した既知物犋を 55 件選び出してこれをブロック 2 のマスターデータとして検 索実験を行った結果，アウトプットは対応する既知物犋を含み 10 件以内に収まり検索は 100\% 成功し良好な結果が得られた。 このことよりマスターデータを 2 万件程度増加してもこれまで 述べた波長のずれの分散, 対応する吸収帯の数及び吸収強度の 相関係数を用いた本検索手法は本実験と同様に良好な結果が得 られると推測される。

なおマスターデータが 2 万件の場合 1 物犋あたりの検索時間 は 30 分以内と推定される。この時の条件はマスターデータを 磁気テープに貯え，入出力装固（i/o）泜低速である。従って磁 気テープのかわりにパックを使用し高速入出力装固を使用すれ ば検索時間は $1 / 10$ から $1 / 50$ に短縮される。Fig. 3 に“F PURE" 実験 No. 2 のアウトプットを示す。

Table 2 The Results of Out Put

\begin{tabular}{|c|c|c|c|c|c|c|c|c|c|}
\hline \multirow{2}{*}{\multicolumn{2}{|c|}{ Sample }} & \multirow{2}{*}{\multicolumn{2}{|c|}{ Correspond Substance }} & \multicolumn{6}{|c|}{ Experimental Conditions } \\
\hline & & & & \multirow{2}{*}{$\begin{array}{c}\text { Ex. No. } 1 \\
\qquad \begin{array}{c}\epsilon=0.1 \\
\rho=1.0\end{array}\end{array}$} & \multirow{2}{*}{$\begin{array}{c}\text { Ex. No. } 2 \\
\varepsilon=0.1 \\
\rho=1.3\end{array}$} & \multirow{2}{*}{$\begin{array}{c}\text { Ex. No. } 3 \\
\begin{array}{c}\epsilon=0.1 \\
\rho=1.6\end{array}\end{array}$} & \multirow{2}{*}{$\begin{array}{c}\text { Ex. No. } 4 \\
\varepsilon=0.2 \\
\rho=1.0\end{array}$} & \multirow{2}{*}{$\begin{array}{c}\text { Ex. No. } 5 \\
\begin{array}{c}\varepsilon=0.2 \\
\rho=1.3\end{array}\end{array}$} & \multirow{2}{*}{$\begin{array}{c}\text { Ex. No. } 6 \\
\begin{array}{c}\epsilon=0.2 \\
\rho=1.6\end{array}\end{array}$} \\
\hline No. & Name & Sadtler No. & & & & & & & \\
\hline \multirow{4}{*}{1} & \multirow{4}{*}{ Sample $\mathbf{H}$} & \multirow{4}{*}{ D1628 } & V & $0.0012^{*}$ & $0.0017^{*}$ & $0.0023^{*}$ & $0.0012^{*}$ & $0.0017^{*}$ & $0.0017^{*}$ \\
\hline & & & $\mathbf{R}$ & $0.8803^{*}$ & $0.8803^{*}$ & $0.8803^{*}$ & $0.8803^{*}$ & $0.8803^{*}$ & $0.8803^{*}$ \\
\hline & & & $\mathbf{B}$ & $9 *$ & $9^{*}$ & $9 *$ & $9 *$ & $9 *$ & $9 *$ \\
\hline & & & $\mathbf{O}$ & 6 & 6 & 6 & 8 & 8 & 8 \\
\hline \multirow{4}{*}{2} & \multirow{4}{*}{ Sample I } & \multirow{4}{*}{ D1640 } & $\mathbf{V}$ & 0.0056 & 0.0143 & 0.0400 & 0.0125 & 0.0605 & 0.2856 \\
\hline & & & $\mathbf{R}$ & $0.6857^{*}$ & $0.6857^{*}$ & $0.6857^{*}$ & 0.7292 & 0.7292 & 0.7292 \\
\hline & & & B & 7 & 7 & 7 & 9 & 9 & 9 \\
\hline & & & O & 5 & 5 & 5 & 9 & 9 & 9 \\
\hline \multirow{4}{*}{3} & \multirow{4}{*}{ DOP PURE } & \multirow{4}{*}{28} & V & 0.0046 & 0.0056 & 0.0070 & $0.0034^{*}$ & $0.0039 *$ & $0.0046^{*}$ \\
\hline & & & $\mathbf{R}$ & $0.8672^{*}$ & $0.8672^{*}$ & $0.8672^{*}$ & $0.9568 *$ & $0.9568^{*}$ & $0.9568^{*}$ \\
\hline & & & $\mathbf{B}$ & 9* & $9 *$ & $9^{*}$ & $10^{*}$ & $10^{*}$ & $10^{*}$ \\
\hline & & & $\mathbf{O}$ & 3 & 3 & 3 & 10 & 10 & 10 \\
\hline \multirow{4}{*}{4} & \multirow{4}{*}{$\mathrm{D} 10 * \mathrm{~T} 1$} & \multirow{4}{*}{28} & $\mathrm{~V}$ & 0.0029 & 0.0037 & $0.0047^{*}$ & 0.0029 & 0.0037 & $0.0047^{*}$ \\
\hline & & & $\mathbf{R}$ & $0.8932^{*}$ & $0.8932^{*}$ & $0.8932^{*}$ & $0.8932^{*}$ & $0.8932^{*}$ & $0.8932^{*}$ \\
\hline & & & B & 9 & 9 & 9 & 9 & 9 & $\mathbf{g}$ \\
\hline & & & 0 & 10 & 10 & 10 & 10 & 10 & 10 \\
\hline \multirow{4}{*}{5} & \multirow{4}{*}{ F PURE } & \multirow{4}{*}{6272} & $\mathrm{~V}$ & $0.0032 *$ & $0.0059 *$ & $0.0100^{*}$ & $0.0041^{*}$ & $0.0072^{*}$ & $0.0114^{*}$ \\
\hline & & & $\mathbf{R}$ & $0.8868^{*}$ & $0.8868^{*}$ & $0.8868^{*}$ & $0.9844^{*}$ & $0.9844^{*}$ & $0.9844^{*}$ \\
\hline & & & B & 9* & $9^{*}$ & $9^{*}$ & $10^{*}$ & $10^{*}$ & $10^{*}$ \\
\hline & & & 0 & 2 & 2 & 2 & 7 & 7 & 7 \\
\hline \multirow{4}{*}{6} & \multirow{4}{*}{ F $20 * \mathrm{M} 1$} & \multirow{4}{*}{6272} & V & $0.0007^{*}$ & $0.0008^{*}$ & $0.0010^{*}$ & $0.0007^{*}$ & $0.0008^{*}$ & $0.0010^{*}$ \\
\hline & & & $\mathbf{R}$ & $0.9931^{*}$ & $0.9931^{*}$ & $0.9931^{*}$ & $0.9931^{*}$ & $0.9931^{*}$ & $0.9931^{*}$ \\
\hline & & & $\mathbf{B}$ & $10^{*}$ & $10^{*}$ & $10^{*}$ & $10^{*}$ & $10^{*}$ & $10^{*}$ \\
\hline & & & 0 & 3 & 3 & 3 & 8 & 8 & 8 \\
\hline \multirow{4}{*}{7} & \multirow{4}{*}{ F $10 * M 1$} & & V & 0.0020 & 0.0027 & $0.0036^{*}$ & $0.0020^{*}$ & $0.0027^{*}$ & $0.0036^{*}$ \\
\hline & & & $\mathbf{R}$ & 0.9510 & 0.9510 & $0.9510^{*}$ & $0.9510^{*}$ & $0.9510^{*}$ & $0.9510^{*}$ \\
\hline & & 6272 & B & $10^{*}$ & $10^{*}$ & $10^{*}$ & $10^{*}$ & $10^{*}$ & $10^{*}$ \\
\hline & & & 0 & 3 & 3 & 3 & 10 & 10 & 10 \\
\hline
\end{tabular}




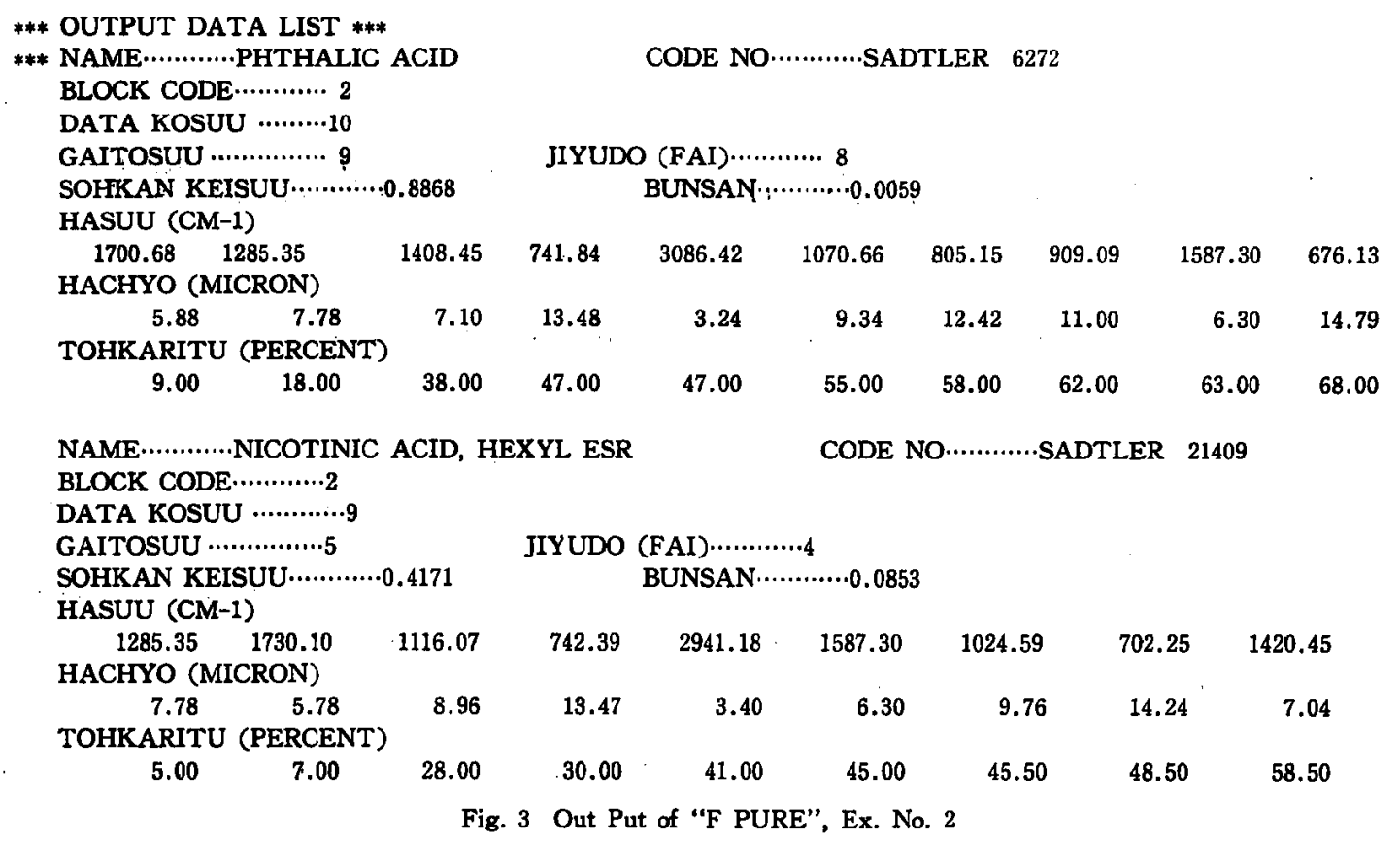

\section{5 括}

赤外線吸収スペクトルの検索に電子計箱機を利用することを 試み、マスターデータが少量であったがそれを溨らためマスタ ーデータの選択において約 5 万件の中より被検試料とスペクト ル上類似した既知物所 55 件を選びマスターデータの一部とし， 検索実験を行った結果次のことが結論つけられる。

1. 電子計算機による本梌索手法は同定しにくいグループか ら主成分に対応する既知物梊を十分選び出すことがわかった。

2. 波長のずれの分散による照合手段は電子計算機による梌 索には有効で,これに対応する吸収带の数及び吸収強度の相関 俰数の三つを組み合わせて判定する。

3. この実験では 10\% 程度の不純物による検索への竝害は 除去できた。

今後マスターデータ数の増加及び吸収帯の数が少ない物啠,
たとえば吸収帯が 4 個程度の物罂の検索についてさらに検討す る予定である。

本研究にあたり，種々御教示を頂き，マスターデータを選択 寸る際“赤外スペクトル検索装置 (TEAC IR-500)”を快く利 用させて下さった東京工業試験所左伯慎之助博士にお礼申し上 げ，併せてプログラムを担当した谷村席夫氏と，また本研究の 投稿を許可して下さった（株）鐵興社並びに（株）テーケーエ ス環境技術センターの上司の方々に感䃟する。

\section{考女增}

1) 佐伯䐜之助, 分析化学, 19, 736 (1970).

2) 估伯慎之助, 分析譏器, 5, (7), 38 (1967).

3) Anderson, D.H., Covert, G.L., Anal. Chem., 39, 1288 (1967).

4) Sebesta, R.W. et al., ibid., 44, 260 (1972)

5) Rann, C.S., ibid., 44, 1669 (1972).

6) Erley, D.S., Appl. Spectrosco., 25, 201 (1971). 